\title{
Erratum: Extraversion and neuroticism relate to topological properties of resting-state brain networks
}

\section{Qing Gao *}

School of Mathematical Sciences, University of Electronic Science and Technology of China, Cheng du, China

${ }^{*}$ Correspondence: qingqing.gao@gmail.com

\section{Edited by:}

Yong He, Beijing Normal University, China

\section{A commentary on}

Extraversion and neuroticism relate to topological properties of resting-state brain networks

by Gao, Q., Xu, Q., Duan, X., Liao, W., Ding, J., Zhang, Z., et al. (2013). Front. Hum. Neurosci. 7:257. doi: 10.3389/fnhum. 2013.00257

In the above paper, two mistakes were discovered after publication.
The corrections are as following:

1. Zhiliang Long needs to be added as the third author.

2. All the " $p<1.90$ " in the paper should be corrected to " $p<1 / 90$."

Received: 11 July 2013; accepted: 20 July 2013; published online: 06 August 2013.
Citation: Gao Q (2013) Erratum: Extraversion and neuroticism relate to topological properties of restingstate brain networks. Front. Hum. Neurosci. 7:448. doi: 10.3389/fnhum.2013.00448

Copyright (c) 2013 Gao. This is an open-access article distributed under the terms of the Creative Commons Attribution License (CC BY). The use, distribution or reproduction in other forums is permitted, provided the original author(s) or licensor are credited and that the original publication in this journal is cited, in accordance with accepted academic practice. No use, distribution or reproduction is permitted which does not comply with these terms. 